\title{
Eslicarbazepine acetate in the treatment of adults with partial-onset epilepsy: an evidence-based review of efficacy, safety and place in therapy
}

This article was published in the following Dove Press journal: Core Evidence

\section{Simona Lattanzi' \\ Francesco Brigo ${ }^{2,3}$ \\ Claudia Cagnetti' \\ Alberto Verrotti ${ }^{4}$ \\ Gaetano Zaccara ${ }^{5}$ \\ Mauro Silvestrini ${ }^{1}$}

'Neurological Clinic, Department of Experimental and Clinical Medicine, Marche Polytechnic University, Via Conca, Ancona, Italy; ${ }^{2}$ Department of Neuroscience, Biomedicine and Movement Science, University of Verona, Italy; ${ }^{3}$ Division of Neurology, "Franz Tappeiner" Hospital, Merano BZ, Italy; ${ }^{4}$ Department of Pediatrics, University of L'Aquila, L'Aquila, Italy; ${ }^{5}$ Unit of Neurology, Department of Medicine, Usl Centro Toscana Health Authority, Firenze, Italy
Correspondence: Simona Lattanzi Neurological Clinic, Department of Experimental and Clinical Medicine, Marche Polytechnic University, Via Conca 7I, 60020 Ancona, Italy

$\mathrm{Tel}+39715964438$

Fax +3971887262

Email alfierelattanzisimona@gmail.com
Introduction: Up to $30 \%$ of the patients diagnosed with epilepsy will continue suffering from seizures despite treatment with antiepileptic drugs, either in monotherapy or polytherapy. Hence, there remains the need to develop new effective and well-tolerated therapies.

Aim: The objective of this article was to review the evidence for the efficacy and safety of eslicarbazepine acetate (ESL) as adjunctive treatment in adult patients with focal onset seizures. Evidence review: ESL is the newest, third-generation, single enantiomer member of the dibenzazepine family. Following oral administration, ESL is rapidly and extensively metabolized by hepatic first-pass hydrolysis to the active metabolite eslicarbazepine, which has linear, doseproportional pharmacokinetics and low potential for drug-drug interactions. Eslicarbazepine works as a competitive blocker of the voltage gated sodium channels; unlike carbamazepine (CBZ) and oxcarbazepine (OXC), it has a lower affinity for the resting state of the channels, and reduces their availability by selectively enhancing slow inactivation. Efficacy and safety of ESL have been assessed in four randomized, Phase III clinical trials: the median relative reduction in standardized seizure frequency was $33.4 \%$ and $37.8 \%$ in the ESL 800 and 1,200 mg daily dose groups, and the responder rates were $33.8 \%$ and $43.1 \%$, respectively. The incidence of treatment-emergent adverse events (TEAEs) increased with raising the dosage (ESL 400 mg: $63.8 \%$, ESL $800 \mathrm{mg}$ : $67.0 \%$, ESL 1,200 mg: 73.1\%). The TEAEs were generally mild to moderate in intensity, and the most common were dizziness, somnolence, headache and nausea. Open-label studies confirmed the findings from the pivotal trials and demonstrated sustained therapeutic effect of ESL over time and improvement of tolerability profile in patients switching from OXC/CBZ. No unexpected safety signals emerged over $>5$ years of follow-up.

Conclusion: Once-daily adjunctive ESL at the doses of 800 and 1,200 $\mathrm{mg}$ was effective to reduce the seizure frequency and was fairly well tolerated in adults with focal onset epilepsy. Starting treatment at $400 \mathrm{mg} /$ day, followed by $400 \mathrm{mg}$ increments every 7-14 days, could provide the optimal balance of efficacy and tolerability.

Keywords: eslicarbazepine acetate, epilepsy, focal seizures, review

Clinical impact summary for eslicarbazepine acetate as adjunctive treatment in patients with focal onset seizures

\begin{tabular}{|c|c|c|}
\hline Outcome measure & Evidence & Implications \\
\hline \multicolumn{3}{|l|}{$\begin{array}{l}\text { Disease-oriented } \\
\text { evidence }\end{array}$} \\
\hline $\begin{array}{l}\text { Seizure frequency } \\
\text { reduction }\end{array}$ & $\begin{array}{l}\text { Randomized, placebo- } \\
\text { controlled, double- } \\
\text { blind, clinical trials and } \\
\text { observational, open-label } \\
\text { studies }\end{array}$ & $\begin{array}{l}\text { Once-daily eslicarbazepine acetate at the dosage } \\
\text { of } 800 \text { and I,200 mg consistently demonstrated } \\
\text { to be effective in the adjunctive treatment } \\
\text { of adult patients presenting with focal onset } \\
\text { seizures. }\end{array}$ \\
\hline
\end{tabular}

(Continued) 
(Continued)

\begin{tabular}{|c|c|c|}
\hline Outcome measure & Evidence & Implications \\
\hline & & $\begin{array}{l}\text { A dose-dependent response occurred with an } \\
\text { increase in effect by increasing the dose. } \\
\text { In the pooled analysis of the Phase III pivotal } \\
\text { trials, the median relative reduction in } \\
\text { standardized seizure frequency was } 33.4 \% \text { and } \\
37.8 \% \text { in the eslicarbazepine acetate } 800 \mathrm{mg} \text { and } \\
\text { I,200 mg daily dose groups and the responder } \\
\text { rates were } 33.8 \% \text { and } 43.1 \% \text {, respectively. The } \\
\text { drug efficacy was demonstrated regardless of } \\
\text { whichever concomitant baseline, antiepileptic } \\
\text { drugs were used. } \\
\text { Open-label studies showed similar results and } \\
\text { demonstrated sustained therapeutic effect of } \\
\text { eslicarbazepine acetate. }\end{array}$ \\
\hline \multicolumn{3}{|l|}{$\begin{array}{l}\text { Patient-oriented } \\
\text { evidence }\end{array}$} \\
\hline Tolerability and safety & $\begin{array}{l}\text { Randomized, placebo- } \\
\text { controlled, double- } \\
\text { blind, clinical trials and } \\
\text { observational, open-label } \\
\text { studies }\end{array}$ & $\begin{array}{l}\text { Once-daily eslicarbazepine acetate was well } \\
\text { tolerated overall as adjunctive treatment in } \\
\text { adults with focal onset epilepsy. } \\
\text { In the pooled analysis of the Phase III trials, } \\
\text { the incidence of treatment-emergent adverse } \\
\text { events increased with increase of the dose } \\
\text { (eslicarbazepine acetate } 400 \mathrm{mg}: 63.8 \% \text {, } \\
\text { eslicarbazepine acetate } 800 \mathrm{mg}: 67.0 \% \text {, } \\
\text { eslicarbazepine acetate I,200 mg: } 73.1 \% \text {; most } \\
\text { of the treatment-emergent adverse events } \\
\text { were mild to moderate in intensity. The most } \\
\text { common were dizziness, somnolence, headache } \\
\text { and nausea. The incidence of adverse events was } \\
\text { higher in patients co-treated with carbamazepine } \\
\text { than with other antiepileptic drugs. } \\
\text { Changes in mean laboratory parameters were } \\
\text { not associated with clinically relevant findings, } \\
\text { and there were no variations in vital signs, } \\
\text { body weight or electrocardiography of clinical } \\
\text { concern. } \\
\text { Hyponatremia leading to treatment } \\
\text { discontinuation occurred in less than I\% of the } \\
\text { patients taking eslicarbazepine acetate. } \\
\text { Similar results were observed in the open-label } \\
\text { studies. Tolerability profile improved in patients } \\
\text { switching from oxcarbazepine/carbamazepine to } \\
\text { eslicarbazepine acetate due to side effects. No } \\
\text { unexpected safety signals emerged over }>5 \text { years } \\
\text { of follow-up. }\end{array}$ \\
\hline Net benefit & $\begin{array}{l}\text { Randomized, placebo- } \\
\text { controlled, double- } \\
\text { blind, clinical trials and } \\
\text { observational, open-label } \\
\text { studies }\end{array}$ & $\begin{array}{l}\text { Starting treatment at the } 400 \mathrm{mg} / \text { day dose, } \\
\text { followed by } 400 \mathrm{mg} \text { increments every } 7-14 \text { days } \\
\text { until the optimal dose is reached, can maximize } \\
\text { the balance of efficacy and tolerability. }\end{array}$ \\
\hline $\begin{array}{l}\text { Economic } \\
\text { evidence }\end{array}$ & Not available & \\
\hline
\end{tabular}

\section{Introduction}

Epilepsy is one of the most common neurological disorders affecting approximately 70 million people worldwide. It has an annual incidence of about 80 cases per 100,000 people and a point prevalence between 4 and 10 cases per 1,000 people. ${ }^{1}$ The treatment of epilepsy is mainly symptomatic and nearly $70 \%$ of all patients have a good prognosis and achieve a longterm remission. However, up to $30 \%$ of adults diagnosed with 
epilepsy will continue suffering from seizures despite treatment with antiepileptic drugs (AEDs), either in monotherapy or polytherapy. ${ }^{2}$ Notably, the inadequate seizure control, which may be related to either pharmacoresistance or intolerable adverse effects, is associated with physical risks and impairments in social opportunities and has a negative influence on overall quality of life. ${ }^{3}$ Hence, there remains the need to develop new effective and well-tolerated treatment options.

Eslicarbazepine acetate (ESL) is a novel AED, which has been approved by the European Medicines Agency and the US Food \& Drug Administration as monotherapy and adjunctive therapy for focal onset seizures (FOS), with or without secondary generalization, in adults, and was recently authorized also in children and adolescents as adjunctive treatment.

This paper provides a review of the available evidence on the efficacy and safety of ESL as adjunctive treatment in adult patients with FOS, and highlights major issues about its actual place in therapy.

\section{Brief pharmacology: chemical structure, pharmacodynamics and pharmacokinetics}

ESL is the newest, third-generation, single enantiomer member of the dibenzazepine family, which also includes carbamazepine (CBZ) (first generation) and oxcarbazepine (OXC) (second generation), and works as a competitive blocker of the voltage gated sodium channels (VGSC). ${ }^{4}$ The structural variation at the 10,11 position of the dibenzazepine nucleus conveys ESL unique pharmacodynamics and pharmacokinetics. ${ }^{5}$ Compared to CBZ, ESL has similar affinity for the inactivated state and a threefold lower affinity for the resting state of the VGSC. Unlikely traditional sodium channel blockers, which interfere with the fast inactivation pathway, ESL reduces the VGSC availability by selectively enhancing slow inactivation, similarly to lacosamide. ${ }^{6,7}$ These properties result in stabilization of hyper-excitable neuronal membranes, inhibition of sustained repetitive production of action potentials characteristic of neurons involved in epilepsy and reduction of long-term channel availability, with a low propensity to disturb physiological function. ${ }^{8}$

ESL is an oral pro-drug that is well absorbed following ingestion, with a bioavailability of approximately $94 \%$, and is rapidly and extensively bio-transformed to its major active metabolite eslicarbazepine (S-licarbazepine) by hepatic firstpass hydrolysis. Accordingly, plasma levels of ESL usually remain below the limit of quantification. ${ }^{9,10}$ The binding of eslicarbazepine to plasma proteins is relatively low $(<40 \%)$ and independent of concentration. Plasma peak dose is attained at 2-3 hours post-dose, and the steady state levels are achieved after 4-5 days of once-daily dosing, consistent with an effective half-life of 20-24 hours..$^{9,10}$ Minor metabolites in plasma include the right isomer of eslicarbazepine (R-licarbazepine) and OXC, which were shown to be active, and the glucuronic acid conjugates of ESL, S-licarbazepine, R-licarbazepine and OXC. ${ }^{9}$ The pharmacokinetics of ESL avoids the toxic product of CBZ degradation (i.e., carbamazepine-10,11-epoxide),${ }^{4}$ and the early peak in plasma and cerebrospinal fluid (CSF) concentrations following immediate-release OXC administration. ${ }^{11}$ Further, ESL does not affect its own metabolism or clearance; eslicarbazepine is a weak inducer of CYP3A4 and UDPglucuronyl transferases, and has inhibiting properties with respect to CYP2C19. ESL metabolites are eliminated from the systemic circulation primarily by renal excretion, in the unchanged and glucuronide conjugate forms; S-licarbazepine and its glucuronide correspond to more than $90 \%$ of total metabolites excreted in urine. ${ }^{9}$ Overall, the pharmacokinetics of ESL are linear, dose-proportional in the 400-1,200 mg range and unaffected by age, sex and food intake., $5,10,12$

\section{Drug formulation and dosing}

ESL is an oral AED available in a liquid suspension or tablet form, which may be taken with or without food. The recommended starting dose of ESL is $400 \mathrm{mg}$ once daily, which should be increased to $800 \mathrm{mg}$ once daily after 1 or 2 weeks; according to individual response, the dose as adjunctive treatment may be increased to $1,200 \mathrm{mg}$ once daily. ${ }^{9}$ The plasma levels show a linear correlation with the posology, but a therapeutic range has not been defined.

\section{Efficacy, tolerability and safety of adjunctive ESL in randomized, placebo controlled, double-blind trials}

The adjunctive therapy program to evaluate the efficacy and tolerability of ESL in adult patients with FOS included one Phase II study (study BIA-2093-201) ${ }^{13}$ and four Phase III, multicenter, randomized, double-blind and placebo controlled clinical trials (studies BIA-2093-301 [NCT00957684], BIA2093-302 [NCT00957047], BIA-2093-303 [NCT00957372] and BIA-2093-304 [NCT00988429]). ${ }^{14-17}$ All the studies recruited patients presenting with at least four FOS per month, with or without secondary generalization, despite treatment with one to three AEDs at a stable dose; notably, OXC was not allowed as a concomitant AED as it has the same pharmacologically active main metabolite with ESL.

In the Phase II study, ${ }^{13} 143$ patients were randomized to treatment with ESL once daily, ESL twice daily, or placebo. 
The ESL daily dose was gradually titrated up to $1,200 \mathrm{mg} /$ day in three steps at 4-week intervals. A statistically significant difference from placebo in the response rate at the end of the 12-week treatment period was found only for the once-daily group, whereas the incidence of adverse events was similar across the arms. Accordingly, ESL has been administered once a day in all the subsequent trials.

All the Phase III trials followed a similar design with ESL administered once daily for 12 weeks (maintenance period); the major differences in trial designs included the number of doses tested and the titration and tapering-off regimens. Studies BIA-2093-301 and BIA-2093-302 had three ESL daily dose groups (400, 800 and 1,200 mg), ${ }^{14,15}$ whereas studies BIA-2093-303 and BIA-2093-304 had only two ESL doses (800 and 1,200 mg) ${ }^{16,17}$ In each of the individual studies, the primary efficacy variable was the 4-week standardized seizure frequency (SSF) over the maintenance period, and the predefined key efficacy outcomes included the median reduction and the $50 \%$ or greater reduction in SSF (response rate) over the maintenance period compared to baseline. Safety assessment included treatment-emergent adverse events (TEAEs), clinical laboratory parameters, vital signs and electrocardiography. The main characteristics and results of the Phase III trials are summarized in the Table 1.

The population in the pivotal four trials was predominantly Caucasian with a mean age of 38 years and a mean disease duration of 22 years. The baseline seizure frequency was approximately 15 seizures/4 weeks, and all patients but five were taking at least one concomitant AED at the end of the baseline period. The most common concomitant drugs were CBZ, lamotrigine and valproic acid. ${ }^{18}$ Overall, results of these studies clearly demonstrated that once-daily ESL at the dosage of 800 or 1,200 $\mathrm{mg}$ is effective and well tolerated as adjunctive treatment in patients with focal onset epilepsy; furthermore, starting treatment at the $400 \mathrm{mg} /$ day dose, followed by $400 \mathrm{mg}$ increments, provides optimal balance of efficacy and tolerability. ${ }^{18}$ In a pooled analysis of the integrated datasets, the median relative reduction in SSF was $17.6 \%$ in the placebo group compared to $23.4 \%, 33.4 \%$ and $37.8 \%$ in the ESL 400,800 and 1,200 mg groups, respectively; the responder rates were $22.9 \%, 33.8 \%$ and $43.1 \%$ for the ESL 400, 800 and 1,200 mg daily doses, respectively, and $22.2 \%$ for the placebo group. ${ }^{18}$ The differences to placebo were statistically significant only for the ESL 800 and 1,200 mg doses; the drug efficacy was demonstrated regardless of whichever concomitant baseline AEDs were used. The overall incidence of TEAEs increased with the increase of ESL dose (ESL $400 \mathrm{mg}$ : 63.8\%, ESL $800 \mathrm{mg}$ : 67.0\%, ESL 1,200 mg: 73.1\%; placebo: $52.7 \%$ ); this trend was also observed for TEAEs leading to drug withdrawal (ESL $400 \mathrm{mg}: 8.7 \%$, ESL $800 \mathrm{mg}$ : $12.2 \%$, ESL 1,200 mg: $22.2 \%$; placebo: $6.2 \%$ ); mainly dizziness and nausea. ${ }^{18}$ The most common TEAEs, reported by at least $10 \%$ of the patients, were dizziness, somnolence, headache and nausea; notably, the incidence of adverse events was higher in patients co-treated with CBZ than with other AEDs. A shift of sodium levels from

Table I Main characteristics and results of the Phase III, randomized, double-blind, placebo-controlled trials of adjunctive eslicarbazepine acetate in patients with refractory focal onset seizures

\begin{tabular}{|c|c|c|c|c|c|c|c|}
\hline $\begin{array}{l}\text { Study } \\
\text { (reference) }\end{array}$ & $\begin{array}{l}\text { AEDs } \\
\text { allowed }\end{array}$ & Titration & Tapering-off & $\begin{array}{l}\text { Treatment } \\
\text { arms }\end{array}$ & $\begin{array}{l}\text { Median relative } \\
\text { reduction in SSF }\end{array}$ & $\begin{array}{l}\text { Reduction in } \\
\text { SSF } \geq \mathbf{5 0} \%\end{array}$ & $\begin{array}{l}\text { Any } \\
\text { TEAEs }\end{array}$ \\
\hline BIA-2093-30I 14 & $\mathrm{I}-2$ & $\begin{array}{l}\text { At } 400 \text { mg weekly } \\
\text { steps }\end{array}$ & $\begin{array}{l}\text { At } 400 \mathrm{mg} \text { weekly } \\
\text { steps until } 0 \mathrm{mg} \\
\text { (PBO) }\end{array}$ & $\begin{array}{l}\mathrm{N}=402 \\
\mathrm{PBO}=102 \\
E S L 400 \mathrm{mg}=100 \\
E S L 800 \mathrm{mg}=98 \\
\text { ESL } \mathrm{I}, 200 \mathrm{mg}=102\end{array}$ & $\begin{array}{l}16.0 \% \\
26.0 \% \\
36.0 \%(p<0.05) \\
45.0 \%(p<0.001)\end{array}$ & $\begin{array}{l}20.0 \% \\
23.0 \% \\
34.0 \%(p<0.05) \\
43.0 \%(p<0.001)\end{array}$ & $\begin{array}{l}31.4 \% \\
44.0 \% \\
50.0 \% \\
60.8 \%\end{array}$ \\
\hline BIA-2093-302 ${ }^{15}$ & $\mathrm{I}-3$ & $\begin{array}{l}\text { No titration in the } \\
400 \text { and } 800 \mathrm{mg} \text { arms; } \\
\text { starting with } 800 \mathrm{mg} \\
\text { in the } 1,200 \mathrm{mg} \text { arm }\end{array}$ & No tapering-off & $\begin{array}{l}\mathrm{N}=395 \\
\mathrm{PBO}=100 \\
E S L 400 \mathrm{mg}=96 \\
E S L 800 \mathrm{mg}=101 \\
\text { ESL } 1,200 \mathrm{mg}=98\end{array}$ & $\begin{array}{l}0.8 \% \\
18.7 \% 3 \\
2.6 \%(p<0.001) \\
32.8 \%(p<0.001)\end{array}$ & $\begin{array}{l}13.0 \% \\
16.7 \% \\
40.0 \%(p<0.001) \\
37.1 \%(p<0.01)\end{array}$ & $\begin{array}{l}68.0 \% \\
78.1 \% \\
83.2 \% \\
79.6 \%\end{array}$ \\
\hline BIA-2093-303 & $\mathrm{I}-2$ & $\begin{array}{l}\text { Starting with half } \\
\text { of the assigned } \\
\text { maintenance dose }\end{array}$ & $\begin{array}{l}\text { At } 2 \text { weeks: half of } \\
\text { the maintenance } \\
\text { dose; at } 2 \text { weeks: } \\
0 \mathrm{mg}(\mathrm{PBO})\end{array}$ & $\begin{array}{l}\mathrm{N}=252 \\
\mathrm{PBO}=87 \\
\mathrm{ESL} 800 \mathrm{mg}=85 \\
\text { ESL } 1,200 \mathrm{mg}=80\end{array}$ & $\begin{array}{l}17.0 \% \\
37.9 \%(p<0.05) \\
41.9 \%(p<0.05)\end{array}$ & $\begin{array}{l}22.6 \\
34.5 \\
37.7(p<0.05)\end{array}$ & $\begin{array}{l}39.1 \% \\
52.9 \% \\
61.3 \%\end{array}$ \\
\hline BIA-2093-304 ${ }^{17}$ & $\mathrm{I}-2$ & $\begin{array}{l}\text { At } 400 \text { mg weekly } \\
\text { steps }\end{array}$ & $\begin{array}{l}\text { At } 400 \mathrm{mg} \text { weekly } \\
\text { steps until } 400 \mathrm{mg}\end{array}$ & $\begin{array}{l}\mathrm{N}=650 \\
\mathrm{PBO}=224 \\
\mathrm{ESL} 800 \mathrm{mg}=216 \\
\text { ESL I, } 200 \mathrm{mg}=210\end{array}$ & $\begin{array}{l}21.8 \% \\
29.7 \% \\
35.6 \%(p<0.05)\end{array}$ & $\begin{array}{l}23.1 \% \\
30.5 \% \\
42.6 \%(p<0.001)\end{array}$ & $\begin{array}{l}55.8 \% \\
67.1 \% \\
77.6 \%\end{array}$ \\
\hline
\end{tabular}

Abbreviations: AED, antiepileptic drug; PBO, placebo; ESL, eslicarbazepine acetate; SSF, standardized seizure frequency; TEAEs, treatment-emergent adverse events. 
normal at baseline to low (i.e., $<135 \mathrm{mEq} / \mathrm{L}$ ) at the end of the maintenance treatment phase was found in $1.8 \%$ of patients treated with placebo, and in $6.1 \%, 4.8 \%$ and $6.6 \%$ of patients treated with ESL 400, 800 and 1,200 mg daily, respectively; hyponatremia leading to treatment discontinuation occurred in less than $1 \%$ of the patients taking ESL. ${ }^{18}$

The incidence of TEAEs was lower in patients who initiated ESL at $400 \mathrm{mg} /$ day, followed by $400 \mathrm{mg}$ increments, than in those starting treatment at higher dosages. ${ }^{18}$ Changes in mean laboratory parameters were not associated with clinically relevant findings, and there were no variations in vital signs, body weight or electrocardiography of clinical concern.

\section{Open-label extension and real-world studies}

Two 1-year, open-label extension studies ${ }^{19,20}$ including patients who completed the randomized pivotal Phase III trials ${ }^{14,15}$ were performed. The starting ESL daily dose was $800 \mathrm{mg}$, which could be individualized thereafter within the 400-1,200 mg range, while keeping stable the dosages of concomitant AEDs. Overall, these studies demonstrated sustained therapeutic effect and favorable long-term safety and tolerability of once-daily adjunctive ESL. A total of 462 patients concluded the 1year of treatment; compared to the baseline period of the corresponding double-blind trial, the median seizure frequency decreased by $32-39 \%$ in weeks $1-4$, and between $37 \%$ and $56 \%$ thereafter. The responder rate was $37-41 \%$ during the first 4 weeks, and then ranged from $38 \%$ to $53 \%$ per 12 -week interval. The proportion of seizure-free patients per 12-week interval ranged between $5.0 \%$ and $12.5 \%$. Adverse events were reported by $51-83 \%$ of the patients; the most common adverse events were dizziness and headache and they were usually of mild to moderate intensity. Significant improvements in quality of life domains and depressive symptoms were also observed.

Different prospective and retrospective real-world studies have been performed after ESL's authorization as adjunctive treatment in FOS: ${ }^{21-30}$ they have provided reassuring evidence of its efficacy and safety in routine clinical care and across different baseline patient conditions, and have complemented data from clinical trials. The characteristics and findings of the main real-life studies are summarized in Table 2.

Table 2 Summary of the real-world studies of adjunctive eslicarbazepine acetate in focal onset seizures

\begin{tabular}{|c|c|c|c|c|}
\hline Study & Study design & Patient characteristics & Main outcome measures & Authors' conclusion \\
\hline $\mathrm{sli}^{21}$ & $\begin{array}{l}\text { Pooled analysis } \\
\text { of I4 European, } \\
\text { prospective and } \\
\text { retrospective } \\
\text { clinical audit } \\
\text { studies* }\end{array}$ & $\begin{array}{l}\mathrm{N}=2,058 \\
\text { Male: } 52.1 \% \\
\text { Age: } 44.0 \text { (I5) years } \\
\text { Epilepsy duration: } 20.9 \text { ( } 16.4 \text { ) years } \\
\text { Baseline monthly seizure } \\
\text { frequency: I3.6 (49.9) } \\
\text { Number of concomitant AEDs: } \\
\text { I.7 (I.0) }\end{array}$ & $\begin{array}{l}\text { Retention rate: } 73.4 \% \text { (1 } 2 \text { months) } \\
\text { Responder rate: } 75.6 \% \text { (12 months) } \\
\text { Seizure freedom: } 41.3 \% \text { ( } 12 \text { months) } \\
\text { AEs: } 34.0 \% \\
\text { Discontinuation due to AEs: } 13.6 \% \\
\text { Most frequent AEs: dizziness (6.7\%), } \\
\text { fatigue ( } 5.4 \%) \text {, somnolence (5.I\%) } \\
\text { ESL more effective in patients aged } \geq 65 \\
\text { years, not receiving treatment with other } \\
\text { sodium channel blockers, receiving <2 } \\
\text { concomitant AEDs }\end{array}$ & $\begin{array}{l}\text { Euro-Esli is the largest ESL } \\
\text { clinical practice study available } \\
\text { to date. } \\
\text { It provides strong and } \\
\text { reassuring evidence of ESL's } \\
\text { safety profile. No unexpected } \\
\text { safety signals emerged over a } \\
\text { median duration of follow-up } \\
\text { of }>5 \text { years. }\end{array}$ \\
\hline ESLADOBA $^{22}$ & $\begin{array}{l}\text { Prospective, } \\
\text { multicenter } \\
\text { (Portugal); ESL as } \\
\text { add-on therapy to } \\
\text { one AED }\end{array}$ & $\begin{array}{l}\mathrm{N}=52 \\
\text { Male: } 48.1 \% \\
\text { Age: } 4 \text { I.5 (I3.3) years } \\
\text { Epilepsy duration: I8.5 (I4.8) years } \\
\text { Baseline monthly seizure } \\
\text { frequency: } 7.5 \text { (I2.7) }\end{array}$ & $\begin{array}{l}\text { Retention rate: } 73.0 \% \text { (6-9 months) } \\
\text { Responder rate: } 71.1 \% \text { (6-9 months) } \\
\text { Seizure freedom: } 39.5 \% \text { (months) } \\
\text { AEs: } 23.1 \% \\
\text { Discontinuation due to AEs: } 9.6 \% \\
\text { Reduction in Clinical Global Impression } \\
\text { of Severity: } 42.1 \%\end{array}$ & $\begin{array}{l}\text { ESL showed good retention } \\
\text { rates, elicited a significant } \\
\text { reduction in seizure frequency } \\
\text { and was well tolerated when } \\
\text { used in clinical practice. }\end{array}$ \\
\hline EARLY-ESLI ${ }^{23}$ & $\begin{array}{l}\text { Retrospective, } \\
\text { multicenter } \\
\text { (Spain), I-year } \\
\text { observational; ESL } \\
\text { as add-on after } \\
\text { first monotherapy } \\
\text { failure }\end{array}$ & $\begin{array}{l}\mathrm{N}=253 \\
\text { Male: } 57.3 \% \\
\text { Age: } 48.7(\mathrm{I}-87) \text { years } \\
\text { Epilepsy duration: } 3(\mathrm{I}-10) \text { years } \\
\text { Baseline monthly seizure } \\
\text { frequency: } 2.9(\mathrm{I} 6 . \mathrm{I}) \\
\text { Final median ESL dose: } 800 \mathrm{mg} / \text { day }\end{array}$ & $\begin{array}{l}\text { Retention rate: } 92.9 \% \text { (1 } 2 \text { months) } \\
\text { Responder rate: } 70.5 \% \text { ( } 3 \text { months), } 79.8 \% \\
\text { (6 months), } 82.5 \% \text { (1 } 2 \text { months) } \\
\text { Seizure freedom: } 37.3 \% \text { ( } 12 \text { months) } \\
\text { AEs: } 31.6 \% \\
\text { Discontinuation due to AEs: } 3.6 \% \\
\text { Most common AEs: somnolence ( } 8.7 \%) \text {, } \\
\text { dizziness (5.1\%). } \\
\text { After starting ESL, } 54.2 \% \text { patients } \\
\text { withdrew the prior monotherapy and } \\
\text { converted to ESL alone }\end{array}$ & $\begin{array}{l}\text { The administration of ESL } \\
\text { after the first monotherapy } \\
\text { failure was associated with an } \\
\text { optimal seizure control and } \\
\text { tolerability profile. Over half } \\
\text { of the patients were converted } \\
\text { to ESL monotherapy during } \\
\text { follow-up. }\end{array}$ \\
\hline
\end{tabular}


Table 2 (Continued)

\begin{tabular}{|c|c|c|c|c|}
\hline Study & Study design & Patient characteristics & Main outcome measures & Authors' conclusion \\
\hline $\mathrm{EPOS}^{24-26}$ & $\begin{array}{l}\text { Prospective, } \\
\text { multicenter } \\
\text { (Europe); ESL as } \\
\text { add-on therapy to } \\
\text { one AED }\end{array}$ & $\begin{array}{l}\mathrm{N}=219 \\
\text { Male: } 57.5 \% \\
\text { Age: } 43(\mathrm{I}-83) \text { years } \\
\text { Epilepsy duration: I } 2.3(0-57.3) \\
\text { years } \\
\text { Seizure frequency over } 3 \text { baseline } \\
\text { months: } 29.3 \text { ( } 95.8) . \\
\text { Non-responder to CBZ: } \mathrm{N}=45 . \\
\text { Age: }>60 \text { yrs } \\
\mathrm{N}=4 \mathrm{I} \\
\text { ESL } 800 \text { mg/day: } 74.3 \% \text {. } \\
\text { Target dose achieved with one } \\
\text { titration step: } 79.3 \% \text {. }\end{array}$ & $\begin{array}{l}\text { Retention rate: } 89.0 \% \text { ( } 3 \text { months), } \\
82.2 \% \text { (6 months) } \\
\text { Responder rate: } 69.9 \% \text { ( } 3 \text { months), } \\
81.8 \% \text { (6 months) } \\
\text { Seizure freedom: } 25.9 \% \text { ( } 3 \text { months), } \\
39.2 \% \text { (6 months) } \\
\text { AEs: } 26.0 \% \\
\text { Discontinuation due to AEs: II.4\% } \\
\text { Most frequent AEs: dizziness ( } 4.6 \%) \text {, } \\
\text { headache (3.2\%), convulsion ( } 3.2 \%) \text {, } \\
\text { fatigue ( } 2.7 \%) \\
\text { Decrease (i.e., improvement) of } \\
\text { QOLIE- } 10 \text { from } 2.9 \text { (baseline) to } 2.4 \\
\text { (3 months) and } 2.1 \text { (6 months) }\end{array}$ & $\begin{array}{l}\text { Adjunctive ESL therapy to } \\
\text { one AED showed favorable } \\
\text { retention, seizure control and } \\
\text { tolerability, and improvement } \\
\text { in quality of life. } \\
\text { ESL in patients less refractory } \\
\text { than those included in clinical } \\
\text { trials led to higher responder } \\
\text { and seizure freedom rates. } \\
\text { ESL was effective and generally } \\
\text { well tolerated in elderly } \\
\text { patients and in those who had } \\
\text { previously not responded to } \\
\text { CBZ therapy. }\end{array}$ \\
\hline Correia et $\mathrm{al}^{27}$ & $\begin{array}{l}\text { Retrospective, } \\
\text { single-center } \\
\text { (Portugal), 2-year } \\
\text { observational }\end{array}$ & $\begin{array}{l}\mathrm{N}=152 \\
\text { Male: } 50.6 \% \\
\text { Age: } 38.5(\mid 4.2) \text { years } \\
\text { Epilepsy duration: } 26.8 \text { (I3.I) years } \\
\text { Baseline monthly seizure } \\
\text { frequency: } 19.7 \text { ( } 32.9) \text {. } \\
\text { Two or more AEDs at baseline: } \\
57.9 \%\end{array}$ & $\begin{array}{l}\text { Retention rate: } 82.9 \% \text { (6 months), } \\
71.3 \% \text { ( } 12 \text { months), } 65.1 \% \text { (I8 months), } \\
62.8 \% \text { ( } 24 \text { months) } \\
\text { Responder rate: } 25.7 \% \text { (6 months), } \\
25.7 \% \text { ( } 12 \text { months), } 19.0 \% \text { (I8 months), } \\
\text { I7.1\% ( } 24 \text { months) } \\
\text { AEs: } 42.1 \% \\
\text { Discontinuation due to AEs: } 21.1 \% \\
\text { Most frequent AEs: dizziness, somnolence } \\
\text { AEs more common in regimens with CBZ }\end{array}$ & $\begin{array}{l}\text { ESL appears to be a clinically } \\
\text { useful add-on AED, with } \\
\text { good safety profile and high } \\
\text { retention rates throughout } \\
2 \text { years, even in a very } \\
\text { refractory group of patients. }\end{array}$ \\
\hline ESLIBASE $^{28}$ & $\begin{array}{l}\text { Retrospective, } \\
\text { multicenter (Spain), } \\
\text { non-interventional }\end{array}$ & $\begin{array}{l}\mathrm{N}=327 \\
\text { Male: } 48.0 \% \\
\text { Age: } 41.9 \text { (I4-87) years } \\
\text { Two or more AEDs at baseline: } \\
78 \% \\
\text { Median ESL daily dose: } 800 \mathrm{mg} \\
\text { ( } 3 \text { months), I,200 mg (6 and } \\
\text { I } 2 \text { months) }\end{array}$ & $\begin{array}{l}\text { Retention rate: } 89.3 \% \text { ( } 3 \text { months), } 80.1 \% \\
\text { (6 months), } 72.5 \% \text { (I } 2 \text { months) } \\
\text { Responder rate: } 46.3 \% \text { ( } 3 \text { months), } 57.9 \% \\
\text { (6 months), 52.5\% (I } 2 \text { months) } \\
\text { Seizure freedom: } 21.0 \% \text { ( } 3 \text { months), } \\
28.0 \% \text { (6 months), } 25.3 \% \text { (I } 2 \text { months) } \\
\text { AEs: } 40.7 \% \text { (I } 2 \text { months) } \\
\text { Discontinuation due to AEs: I6.2\% } \\
\text { (I2 months) } \\
\text { Most common AEs: dizziness/nausea } \\
\text { (I I.3\%), somnolence (6.I\%), ataxia (5.I\%) }\end{array}$ & $\begin{array}{l}\text { ESL was well tolerated and } \\
\text { effective over I year. The } \\
\text { responder rate increased } \\
\text { when ESL was combined } \\
\text { with a non-sodium channel- } \\
\text { targeting drug. } \\
\text { Tolerability profile improved in } \\
>50 \% \text { of the patients switching } \\
\text { from OXC/CBZ to ESL due } \\
\text { to AEs. }\end{array}$ \\
\hline Massot et $\mathrm{al}^{29}$ & $\begin{array}{l}\text { Observational, } \\
\text { single-center } \\
\text { (Spain), descriptive, } \\
\text { cross-sectional }\end{array}$ & $\begin{array}{l}\mathrm{N}=6 \mathrm{I} \\
\text { Male: } 31.5 \% \\
\text { Age: } 43.6(14.4) \text { years } \\
\text { Baseline monthly seizure } \\
\text { frequency: } 5.5 \text { (I.13-30). } \\
\text { ESL } 800 \mathrm{mg} / \text { day: } 42.6 \% . \\
\text { Mean follow-up duration: } 4.7 \\
\text { (3.2) months }\end{array}$ & $\begin{array}{l}\text { Retention rate: } 75.4 \% \text { ( } 3 \text { months) } \\
\text { Reduction of monthly median seizure } \\
\text { frequency by } 63.6 \% \\
\text { AEs: } 57.4 \% \\
\text { Most common AE: dizziness ( } 34.4 \% \text { ) } \\
\text { Twelve patients ( } 19.7 \% \text { ) switched } \\
\text { overnight to ESL from OXC (ratio } \\
\text { I:I), and I } 3 \text { patients ( } 2 \text { I. } 3 \% \text { ) switched } \\
\text { overnight from CBZ to ESL (ratio I:I.3). } \\
\text { At } 3 \text { months after the transition, median } \\
\text { frequency decreased by } 20 \% \text {. }\end{array}$ & $\begin{array}{l}\text { ESL is effective in the } \\
\text { treatment of focal epilepsies } \\
\text { and its early retention rate is } \\
>70 \% \text {. } \\
\text { AEs mostly occurred during } \\
\text { the titration phase. }\end{array}$ \\
\hline $\begin{array}{l}\text { Serrano- } \\
\text { Castro et } \mathrm{al}^{30}\end{array}$ & $\begin{array}{l}\text { Observational } \\
\text { single-center } \\
\text { (Spain) }\end{array}$ & $\begin{array}{l}\mathrm{N}=105 \\
\text { Male: } 51.4 \%\end{array}$ & $\begin{array}{l}\text { Responder rate: } 58.4 \% \text { ( } 6 \text { months) } \\
\text { Seizure freedom: } 20.7 \% \text { ( } 6 \text { months) } \\
\text { AEs: } 18.1 \% \text { ( } 6 \text { months) } \\
\text { Most common AE: cognitive disorders. } \\
\text { Treatment discontinuation: } 1 \text { I.5\%. }\end{array}$ & $\begin{array}{l}\text { ESL is well tolerated and } \\
\text { effective as an add-on therapy } \\
\text { with most of the AEDs. } \\
\text { Add-on to lacosamide was } \\
\text { less effective; association } \\
\text { with other sodium channel } \\
\text { inhibitors had similar efficacy } \\
\text { than others combinations with } \\
\text { other AEDs. }\end{array}$ \\
\hline
\end{tabular}

Notes: *Including the ESLADOBA, Early-Esli, EPOS, Correia et al, ESLIBASE and Massot et al studies. Data are presented as mean (standard deviation) or median (interquartile range).

Abbreviations: AE, adverse event; AED, antiepileptic drug; CBZ, carbamazepine; ESL, eslicarbazepine acetate; OXC, oxcarbazepine; QOLIE-I0, Quality of Life in Epilepsy Inventory-10. 


\section{Clinical use}

\section{Renal and hepatic impairment}

ESL metabolites are eliminated from the systemic circulation primarily by renal excretion, and clearance is dependent on kidney function in patients with mild to severe renal impairment. Dose adjustment is not required if creatinine clearance $(\mathrm{CrCl})$ is $>60 \mathrm{~mL} / \mathrm{min}$; in patients with $\mathrm{CrCl}$ between 30 and $60 \mathrm{~mL} / \mathrm{min}$, the initial ESL dose should be $200 \mathrm{mg}$ once daily or $400 \mathrm{mg}$ every other day for 2 weeks, followed by a oncedaily dose of $400 \mathrm{mg}$, which may be increased up to $600 \mathrm{mg} /$ day on the basis of individual response. ESL is not recommended in patients with severe renal impairment $(\mathrm{CrCl}<30$ $\mathrm{mL} / \mathrm{min}$ ) due to insufficient data. Hemodialysis partially removes ESL and its metabolites from plasma. The liver function has less critical effects on the pharmacokinetics of ESL, and patients with mild to moderate hepatic impairment do not need dosage adjustment. Conversely, the drug has not been evaluated in the presence of severe liver dysfunction, and its use is not recommended in this setting. ${ }^{9}$

\section{Drug interactions}

An increase in the dose of the medicinal products that are mainly metabolized through CYP3A4 (e.g., simvastatin) or eliminated by conjugation through the UDP-glucuronyl transferases may be required when co-administered with ESL due to its inducer effect, albeit weaker than CBZ. Eslicarbazepine has inhibiting properties with respect to CYP2C19, and interactions can arise when ESL is taken with drugs that are substrates of this enzyme (e.g., diazepam).

\section{Oral anticoagulants and digoxin}

ESL at the 1,200 mg daily dose decreases plasma exposure to S-warfarin by $23 \%$, without significant effects on the R-warfarin pharmacokinetics or coagulation: due to interindividual variability in the interaction, it is, however, advisable to carefully monitor the international normalized ratio during the first weeks after initiation or ending concomitant treatment of warfarin and ESL. No studies have specifically assessed whether pharmacological interactions exist between ESL and the direct oral anticoagulants. No influence of ESL on digoxin pharmacokinetics has been observed, suggesting the lack of meaningful interactions with the transporter P-glycoprotein. ${ }^{9}$

\section{Antiepileptic drugs}

The co-administration of ESL and CBZ results in an average decrease of $32 \%$ in exposure to eslicarbazepine, most likely caused by an induction of glucuronidation; this may require an increase of ESL dose. Remarkably, the concomitant treatment with ESL and CBZ can increase the risk to develop diplopia, abnormal coordination and dizziness.

The concomitant use of ESL and phenytoin determines a reduction of one-third in exposure to the active metabolite eslicarbazepine, due to an induction of glucuronidation, and an increase of $31-35 \%$ in exposure to phenytoin, caused by CYP2C19 inhibition. Accordingly, based upon individual response, the dose of ESL may need to be increased and the dose of phenytoin to be decreased.

Data from healthy subjects revealed minor pharmacokinetic interactions between ESL and lamotrigine (15\% decrease in exposure to lamotrigine) or topiramate (18\% decrease in exposure to topiramate). ESL does not appear to interact significantly with levetiracetam and valproate. ${ }^{9}$ Notably, concomitant use of ESL with OXC is not recommended since it may cause overexposure to the active metabolites.

\section{Oral contraceptives}

Eslicarbazepine may decrease the effectiveness of hormonal contraception: the administration of ESL (1,200 mg/day) to female subjects using combined oral contraceptives showed an average decrease in systemic exposure to levonorgestrel of $37 \%$ and to ethinylestradiol of $42 \%$ owing to the CYP3A 4 induction. Therefore, to avoid inadvertent pregnancy, women of childbearing potential may need an increase in oral contraceptive dose or use alternative methods of contraception during ESL treatment and up to the end of the current menstrual cycle after treatment has been stopped. ${ }^{9}$

\section{Fertility, pregnancy and lactation}

Epilepsy is a common neurologic disorder and the majority of affected people are expected to participate fully in life experiences, including childbearing. The prevalence of epilepsy among pregnant women is up to $0.7 \%$, and from three to five births per thousand will be to women with epilepsy. ${ }^{31,32}$ Worldwide registries and observational studies have provided consistent findings on the risks related to both epilepsy itself and many of the older antiepileptic medicinal products, while there remains a large gap in the knowledge of most of the newer ones, including ESL. ${ }^{33}$ In studies in mice, impairment of fertility has been shown after treatment with ESL, like a decrease in implantations and live embryos. ESL has no teratogenic effects in the rat or rabbit, but induced skeletal abnormalities in the mouse. Ossification delays, reduced fetal weights, increases in minor skeletal and visceral anomalies 
were observed at maternal toxic doses in embryo-toxicity studies in mice, rats and rabbits. ${ }^{9}$ Additionally, animal studies have shown excretion of eslicarbazepine in breast milk. To date, there are insufficient data to allow conclusions about the safety of ESL in pregnant women, and it is unknown whether it is excreted in human milk. Accordingly, specialist advice should be given to women who become or plan to become pregnant while receiving ESL.

\section{Elderly population (over 65 years of age)}

A post-approval commitment, multicenter, open-label, noncontrolled, single-arm study (BIA-2093-401 [NCT01422720]) with flexible dose of ESL between 400 and 1,200 mg daily was performed to address the safety and efficacy of ESL as adjunctive treatment in the elderly. Among 72 patients treated with one or two concomitant AEDs, the ESL dose did not exceed $800 \mathrm{mg} /$ day in the majority of the cases. The treatment was associated with a $54 \%$ relative reduction in the standardized baseline seizure frequency and did not raise major safety concerns. The overall frequency of TEAEs $(65.3 \%)$ was similar to the rate observed in the pooled Phase III studies, and the most common were dizziness (12.5\%) and somnolence (9.7\%); notably, the incidence of hyponatremia $(8.3 \%)$ was slightly higher than the proportion observed in the randomized clinical trials. Overall, $25 \%$ of the subjects discontinued prematurely due to side effects. ${ }^{34}$

A retrospective survey that included elderly patients with focal seizures who started ESL in 12 Spanish hospitals, according to real-life experience between 2010 and 2012, was reported as part of the ESLIBASE study. In all, 29 patients with a mean age of 71.2 years were included, of whom 18 were pharmacoresistant. At 1 year, the mean ESL daily dose was $850 \mathrm{mg}$ and the retention rate was $69 \%$. Sixty-two percent of the patients were seizure responders, and $24.1 \%$ were free from seizures. Adverse effects were experienced by $55.2 \%$ of the study cohort and led to treatment discontinuation in seven $(24.1 \%)$ cases. The most common side effects were dizziness, nausea and ataxia; the tolerability profile improved in most of the patients who switched from CBZ or OXC to ESL. ${ }^{35}$ In a single-center, retrospective study of patients treated with ESL, there was no significant difference in the prevalence of mild adverse effects between young and elderly ( $\geq 60$ years old) adults, whereas adverse effects leading to treatment discontinuation were more frequent in the elderly group. ${ }^{36}$ Notably, the pharmacokinetic profile of ESL is unaffected in the elderly and no dose adjustment is needed, provided that renal function is preserved $(\mathrm{CrCl}>60 \mathrm{~mL} / \mathrm{min}) .{ }^{9}$

\section{Transitioning from OXC or CBZ to ESL}

The switch from OXC to ESL is easy to perform: a dose ratio of 1:1 should be employed to estimate the ESL target dose, transition can take place overnight and no changes to co-medication are required. ${ }^{37}$ Conversely, the change from CBZ to ESL is less straightforward and requires careful considerations on a patient-by-patient basis: a dose ratio of $1: 1.3$ should be considered, the conversion period should last a minimum of 1-2 weeks, although longer intervals may be advised, and concomitant medications metabolized by cytochrome enzymes may require dose adjustment. ${ }^{37}$

Transition to ESL might be appropriate in patients who experience or are at risk to develop CBZ- or OXC-related adverse events, including metabolic disorders resulting from enzyme induction like hypercholesterolemia, osteoporosis or sexual dysfunction, in patients who are poorly compliant with two- or three-daily dosing regimen, frequently forget to take their medication or work rotating shifts, and in patients who are poly-medicated or affected by cognitive dysfunction or liver disease. ${ }^{37,38}$ Notably, epilepsy is common among patients with cognitive impairment and dementia, ${ }^{39}$ and the good profile of ESL with respect to neurocognitive functioning can make it a preferable option over AEDs, like CBZ, characterized by deeper effects on psychomotor performance. ${ }^{40,41}$ In this regard, a recent network meta-analysis has compared the tolerability of the new-generation sodium blocker AEDs in drug-resistant epilepsies from doubleblind, placebo-controlled trials. At the highest recommended doses, treatment withdrawal was more frequently observed in patients treated with OXC than with ESL and lacosamide, and vestibulocerebellar side effects including abnormal coordination, ataxia and diplopia were more common among patients taking OXC rather than ESL. ${ }^{42}$

Overall, ESL has been shown to be less frequently associated with cutaneous reactions in comparison to CBZ, and the lack of a toxic epoxide derivative could reduce the risk of developing rash. ${ }^{10}$ In patients known to be positive for HLA-B*1502 or HLA-A*3101, medications other than CBZ should be used and, due to possible cross-reactivity, CBZrelated compounds such as OXC should also be avoided. ${ }^{43}$ In this respect, the official summary of product characteristics contraindicates ESL in patients with hypersensitivity reactions to $\mathrm{CBZ} .{ }^{9}$ A recent report described the case of a patient with the HLA-A*31:01 haplotype who, after the development of a severe cutaneous reaction following CBZ administration, was successfully prescribed ESL without experiencing any adverse event, ${ }^{44}$ and it suggested that ESL may be considered if the benefits are thought to exceed the risks. The safety of 
ESL in subjects with HLA-B*15:02 or HLA-A*31:01 haplotypes and a history of CBZ- or OXC-induced hypersensitivity reactions remain, however, to be fully addressed in larger studies before drawing definitive conclusions.

The overnight OXC-ESL transition resulted in improvements in side effects, quality of life and alertness, while maintaining seizure control. ${ }^{45,46}$ In addition, compared with the first- and second-generation dibenzazepine as well as the traditional inducer AEDs, ESL may be preferred in patients at higher vascular risk $^{47,48}$ by exhibiting a safer profile according to lipid metabolism and atherosclerosis development. ${ }^{49-51}$

Apart from the selective interaction with the inactive state of the VGSC and the reduction of their availability by interfering with the slow inactivation pathway, distinctive properties of ESL include the blockade of high- and lowaffinity hCaV3.2 inward currents with a 10-60-fold higher potency than CBZ, the lack of effect upon KV7.2 outward currents and the block of T-type CaV3.2 channels. Moreover, while $\mathrm{CBZ}$ and $\mathrm{OXC}$ show pro-epileptic actions at clinically relevant concentrations through the enhancement of the excitatory post-synaptic transmission, ESL has no effects on post-synaptic currents, explaining its lack of seizure exacerbation. ${ }^{52,53}$ ESL may not only suppress seizure activity, but also inhibit the generation of a hyperexcitable network, and it can overcome cellular mechanisms of resistance to sodium-channel acting AEDs. ${ }^{52,54}$ In this respect, a real-world clinical experience has suggested that ESL may represent an effective therapeutic option even in those patients who have previously tried, but discontinued the older carboxamides, regardless of the reasons for discontinuation. ${ }^{55}$

\section{Conclusion}

Once-daily ESL at the doses of 800 and 1,200 $\mathrm{mg}$ showed consistent results across efficacy and safety endpoints both in randomized-controlled and open-label studies. Notably, starting treatment at $400 \mathrm{mg}$ /day, followed by $400 \mathrm{mg}$ increments every 7-14 days up to the optimal dose, could maximize the balance between seizure control and tolerability. ${ }^{18}$

Despite the lack of direct comparisons, the distinctive chemical structure of ESL compared to the older members of the dibenzazepine family, $\mathrm{CBZ}$ and $\mathrm{OXC}$, can convey it unique advantages, including the once-daily regimen, the lower potential for drug-drug interactions and the more favorable tolerability profile, while enjoying similar efficacy. Additionally, ESL has shown the potential to be effective in syndromes characterized by high refractoriness to drug treatment, like the mesial temporal lobe epilepsy associated with hippocampal sclerosis. ${ }^{56}$

In conclusion, ESL represents an interesting improvement on a classic drug family for the treatment of FOS, and it has the potential to enhance the quality of life for drug-refractory patients. ${ }^{57}$

\section{Disclosure}

FB acted as consultant for Eisai. GZ has received speaker or consultancy fees from Eisai, Sanofi-Aventis and UCB Pharma. The authors report no other conflicts of interest in this work.

\section{References}

1. Hirtz D, Thurman DJ, Gwinn-Hardy K, Mohamed M, Chaudhuri AR, Zalutsky R. How common are the "common" neurologic disorders? Neurology. 2007;68(5):326-337.

2. Cockerell OC, Johnson AL, Sander JW, Hart YM, Shorvon SD. Remission of epilepsy: results from the national general practice study of epilepsy. Lancet. 1995;346(8968):140-144.

3. Lattanzi S, Cagnetti C, Foschi N, Provinciali L, Silvestrini M. Brivaracetam add-on for refractory focal epilepsy: a systematic review and meta-analysis. Neurology. 2016;86(14):1344-1352.

4. Benes J, Parada A, Figueiredo AA, et al. Anticonvulsant and sodium channel-blocking properties of novel 10,11-dihydro-5H-dibenz [b, f] azepine-5-carboxamide derivatives. J Med Chem. 1999;42(14):2582-2587.

5. Almeida L, Soares-da-Silva P. Eslicarbazepine acetate (BIA 2-093). Neurotherapeutics. 2007;4(1):8896.

6. Hebeisen S, Pires N, Loureiro AI, et al. Eslicarbazepine and the enhancement of slow inactivation of voltage-gated sodium channels: a comparison with carbamazepine, oxcarbazepine and lacosamide. Neuropharmacology. 2015;89:122-135.

7. Lattanzi S, Cagnetti C, Foschi N, Provinciali L, Silvestrini M. Lacosamide monotherapy for partial onset seizures. Seizure. 2015;27:71-74.

8. Almeida L, Bialer M, Soares-da-Silva P. Eslicarbazepine acetate. In: Shorvon S, Perucca E, Engel J, editors. The Treatment of Epilepsy. 3rd ed. Oxford: Wiley-Blackwell; 2009:485-498.

9. European Medicines Agency. Zebinix (eslicarbazepine acetate tablets) summary of product characteristics [online]. Available from: http://www. ema.europa.eu/docs/en_GB/document_library/EPAR_-_Product_Information/human/000988/WC500047225.pdf. Accessed December 30, 2017.

10. Bialer M, Soares-da-Silva P. Pharmacokinetics and drug interactions of eslicarbazepine acetate. Epilepsia. 2012;53(6):935-946.

11. Nunes T, Rocha JF, Falcão A, Almeida L, Soares-da-Silva P. Steadystate plasma and cerebrospinal fluid pharmacokinetics and tolerability of eslicarbazepine acetate and oxcarbazepine in healthy volunteers. Epilepsia. 2013;54(1):108-116.

12. Almeida L, Falcão A, Maia J, Mazur D, Gellert M, Soares-da-Silva P. Single-dose and steady-state pharmacokinetics of eslicarbazepine acetate (BIA 2-093) in healthy elderly and young subjects. J Clin Pharmacol. 2005;45(9):1062-1066.

13. Elger C, Bialer M, Cramer JA, Maia J, Almeida L, Soares-da-Silva P. Eslicarbazepine acetate: a double-blind, add-on, placebo-controlled exploratory trial in adult patients with partial-onset seizures. Epilepsia. 2007;48(3):497-504.

14. Elger C, Halász P, Maia J, Almeida L, Soares-da-Silva P; BIA-2093301 Investigators Study Group. Efficacy and safety of eslicarbazepine acetate as adjunctive treatment in adults with refractory partial-onset seizures: a randomized, double-blind, placebo-controlled, parallel-group phase III study. Epilepsia. 2009;50(3):454- 463. 
15. Ben-Menachem E, Gabbai AA, Hufnagel A, Maia J, Almeida L, Soaresda-Silva P. Eslicarbazepine acetate as adjunctive therapy in adult patients with partial epilepsy. Epilepsy Res. 2010;89(2-3):278-285.

16. Gil-Nagel A, Lopes-Lima J, Almeida L, Maia J, Soares-da-Silva P; BIA-2093-303 Investigators Study Group. Efficacy and safety of 800 and $1200 \mathrm{mg}$ eslicarbazepine acetate as adjunctive treatment in adults with refractory partial-onset seizures. Acta Neurol Scand. 2009;120(5): 281-287.

17. Sperling MR, Abou-Khalil B, Harvey J, et al; 304 Study Team. Eslicarbazepine acetate as adjunctive therapy in patients with uncontrolled partial-onset seizures: results of a phase III, double-blind, randomized, placebo-controlled trial. Epilepsia. 2015;56(2):244-253.

18. Elger C, Koepp M, Trinka E, et al. Pooled efficacy and safety of eslicarbazepine acetate as add-on treatment in patients with focal-onset seizures: data from four double-blind placebo-controlled pivotal phase III clinical studies. CNS Neurosci Ther. 2017;23(12):961-972.

19. Halász P, Cramer JA, Hodoba D, et al; BIA-2093-301 Study Group. Long-term efficacy and safety of eslicarbazepine acetate: results of a 1-year open-label extension study in partial-onset seizures in adults with epilepsy. Epilepsia. 2010;51(10):1963-1969.

20. Hufnagel A, Ben-Menachem E, Gabbai AA, Falcão A, Almeida L, Soares-da-Silva P. Long-term safety and efficacy of eslicarbazepine acetate as adjunctive therapy in the treatment of partial-onset seizures in adults with epilepsy: results of a 1-year open-label extension study. Epilepsy Res. 2013;103(2-3):262-269.

21. Villanueva V, Holtkamp M, Delanty N, Rodriguez-Uranga J, McMurray R, Santagueda P. Euro-Esli: a European audit of real-world use of eslicarbazepine acetate as a treatment for partial-onset seizures. $J$ Neurol. 2017;264(11):2232-2248.

22. Chaves J, Breia P, Pimentel J, et al. Eslicarbazepine acetate as adjunctive therapy in clinical practice: ESLADOBA study. Acta Neurol Scand. 2017;136(5):407-413.

23. Villanueva V, Bermejo P, Montoya J, et al. EARLY-ESLI study: longterm experience with eslicarbazepine acetate after first monotherapy failure. Acta Neurol Scand. 2017;136(3):254-264.

24. Holtkamp M, McMurray R, Bagul M, Sousa R, Kockelmann E. Real-world data on eslicarbazepine acetate as add-on to antiepileptic monotherapy. Acta Neurol Scand. 2016;134(1):76-82.

25. McMurray R, Karlsson C, Sousa R, Holtkamp M. Eslicarbazepine acetate as add-on treatment to antiepileptic monotherapy in patients with partial-onset seizures who previously did not respond to carbamazepine: real-world evidence from the EPOS study (abstract 2.258). Available from: https://www.aesnet.org/meetings_events/ annual_meeting_abstracts/view/2326709. Accessed December 30, 2017.

26. Karlsson C, McMurray R, Sousa R, Holtkamp M (2015). Real world data on eslicarbazepine acetate as add-on treatment to antiepileptic monotherapy in elderly patients ( $>60$ years) with partial-onset seizures (abstract 2.261). Available from: https://www.aesnet.org/meetings_ events/annual_meeting_abstracts/view/2326906. Accessed December 30, 2017.

27. Correia FD, Freitas J, Magalhães R, Lopes J, Ramalheira J, Lopes-Lima J, Chaves J. Two-year follow-up with eslicarbazepine acetate: a consecutive, retrospective, observational study. Epilepsy Res. 2014;108(8): 1399-1405.

28. Villanueva V, Serratosa JM, Guillamón E, et al. Long-term safety and efficacy of eslicarbazepine acetate in patients with focal seizures: results of the 1-year ESLIBASE retrospective study. Epilepsy Res. 2014;108(7):1243-1252.

29. Massot A, Vivanco R, Principe A, Roquer J, Rocamora R. [Postauthorisation study of eslicarbazepine as treatment for drug-resistant epilepsy: preliminary results.] Neurologia. 2014;29(2):94-101. Spanish [with English abstract].

30. Serrano-Castro PJ, Payán-Ortiz M, Cimadevilla JM, Quiroga-Subirana P, Fernández-Pérez J. [Eslicarbazepine acetate in clinical practice. Efficacy and safety results]. Rev Neurol. 2013;56(6):309-314. Spanish [with English abstract].
31. Harden CL, Meador KJ, Pennell PB, et al; American Academy of Neurology; American Epilepsy Society. Practice parameter update: management issues for women with epilepsy-focus on pregnancy (an evidence-based review): teratogenesis and perinatal outcomes: report of the Quality Standards Subcommittee and Therapeutics and Technology Assessment Subcommittee of the American Academy of Neurology and American Epilepsy Society. Neurology. 2009;73(2):133-141.

32. Cagnetti C, Lattanzi S, Foschi N, Provinciali L, Silvestrini M. Seizure course during pregnancy in catamenial epilepsy. Neurology. 2014;83(4): 339-344.

33. Lattanzi S, Cagnetti C, Foschi N, Provinciali L, Silvestrini M. Lacosamide during pregnancy and breastfeeding. Neurol Neurochir Pol. 2017;51(3):266-269.

34. Costa R, Oliveira C, Lopes N, Gama H, Sousa R, Nunes T, Soaresda-Silva P. Safety and efficacy of eslicarbazepine acetate treatment in elderly patients [abstract P340]. Epilepsia. 2014;55(Suppl 2):112.

35. Gómez-Ibáñez A, Serratosa JM, Guillamón E, et al. Efficacy and safety of eslicarbazepine-acetate in elderly patients with focal epilepsy: case series. Seizure. 2017;48:53-56.

36. Nielsen MK, Petrenaite V, Andersen NB. Clinical experience with eslicarbazepine acetate in adults with sub-analysis of elderly. Seizure. 2017;53:94-99.

37. Peltola J, Holtkamp M, Rocamora R, Ryvlin P, Sieradzan K, Villanueva V. Practical guidance and considerations for transitioning patients from oxcarbazepine or carbamazepine to eslicarbazepine acetate-Expert opinion. Epilepsy Behav. 2015;50:46-49.

38. Villanueva V, Ojeda J, Rocamora RA, et al. EPICON consensus: recommendations for proper management of switching to eslicarbazepine acetate in epilepsy. Neurologia. Epub 2016 Jun 24.

39. Lattanzi S, Luzzi S, Provinciali L, Silvestrini M. Blood pressure variability in Alzheimer's disease and frontotemporal dementia: the effect on the rate of cognitive decline. JAlzheimers Dis. 2015;45(2):387-394.

40. Milovan D, Almeida L, Romach MK, et al. Effect of eslicarbazepine acetate and oxcarbazepine on cognition and psychomotor function in healthy volunteers. Epilepsy Behav. 2010;18(4):366-373.

41. Mecarelli O, Vicenzini E, Pulitano P, et al. Clinical, cognitive, and neurophysiologic correlates of short-term treatment with carbamazepine, oxcarbazepine, and levetiracetam in healthy volunteers. Ann Pharmacother. 2004;38(11):1816-1822.

42. Zaccara G, Giovannelli F, Maratea D, Fadda V, Verrotti A. Neurological adverse events of new generation sodium blocker antiepileptic drugs. Meta-analysis of randomized, double-blinded studies with eslicarbazepine acetate, lacosamide and oxcarbazepine. Seizure. 2013;22(7):528-536.

43. Amstutz U, Shear NH, Rieder MJ, et al; CPNDS clinical recommendation group. Recommendations for HLA-B*15:02 and HLA-A*31:01 genetic testing to reduce the risk of carbamazepine-induced hypersensitivity reactions. Epilepsia. 2014;55(4):496-506.

44. Kay L, Willems LM, Zöllner JP, et al. Eslicarbazepine acetate as a therapeutic option in a patient with carbamazepine-induced rash and HLA-A*31:01. Seizure. 2017;47:81-82.

45. Mäkinen J, Rainesalo S, Peltola J. Transition from oxcarbazepine to eslicarbazepine acetate: a single center study. Brain Behav. 2017;7(3):e00634.

46. Schmid E, Kuchukhidze G, Kirschner M, et al. Overnight switching from oxcarbazepine to eslicarbazepine acetate: an observational study. Acta Neurol Scand. 2017;135(4):449-453.

47. Lattanzi S, Carbonari L, Pagliariccio G, et al. Neurocognitive functioning and cerebrovascular reactivity after carotid endarterectomy. Neurology. 2018;90(4):e307-e315.

48. Lattanzi S, Cagnetti C, Provinciali L, Silvestrini M. How should we lower blood pressure after cerebral hemorrhage? A systematic review and meta-analysis. Cerebrovasc Dis. 2017;43(5-6):207-213.

49. Serrano-Castro PJ, Fernández-Pérez J, López-González FJ, et al; ESLLIPID Study Group. Eslicarbazepine acetate and carotid intima-media thickness in epileptic patients. Epilepsy Res. 2017;138:81-87.

50. Pulitano P, Franco V, Mecarelli O, Brienza M, Davassi C, Russo E. Effects of eslicarbazepine acetate on lipid profile and sodium levels in patients with epilepsy. Seizure. 2017;53:1-3. 
51. Ley M, Principe A, Jiménez-Conde J, Rocamora R. Assessing long-term effects of eslicarbazepine acetate on lipid metabolism profile, sodium values and liver function tests. Epilepsy Res. 2015;115:147-152.

52. Soares-da-Silva P, Pires N, Bonifácio MJ, Loureiro AI, Palma N, Wright LC. Eslicarbazepine acetate for the treatment of focal epilepsy: an update on its proposed mechanisms of action. Pharmacol Res Perspect. 2015;3(2):e00124.

53. Booker SA, Pires N, Cobb S, Soares-da-Silva P, Vida I. Carbamazepine and oxcarbazepine, but not eslicarbazepine, enhance excitatory synaptic transmission onto hippocampal CA1 pyramidal cells through an antagonist action at adenosine A1 receptors. Neuropharmacology. 2015;93: 103-115.
54. Doeser A, Dickhof G, Reitze M, et al. Targeting pharmacoresistant epilepsy and epileptogenesis with a dual-purpose antiepileptic drug. Brain. 2015;138 (Pt 2):371-387.

55. Lattanzi S, Cagnetti C, Foschi N, Lorusso A, Provinciali L, Silvestrini M. Eslicarbazepine acetate as adjunctive treatment in partial-onset epilepsy. Acta Neurol Scand. 2018;137(1):29-32.

56. Palleria C, Coppola A, Citraro R, et al. Perspectives on treatment options for mesial temporal lobe epilepsy with hippocampal sclerosis. Expert Opin Pharmacother. 2015;16(15):2355-2371.

57. Galiana GL, Gauthier AC, Mattson RH. Eslicarbazepine acetate: a new improvement on a classic drug family for the treatment of partial-onset seizures. Drugs R D. 2017;17(3):329-339.

\section{Core Evidence}

\section{Publish your work in this journal}

Core Evidence is an international, peer-reviewed open-access journal evaluating the evidence underlying the potential place in therapy of drugs throughout their development lifecycle from preclinical to post launch. The focus of each review is to evaluate the case for a new drug or class in outcome terms in specific indications and patient groups.

Submit your manuscript here: https://www.dovepress.com/core-evidence-journal

\section{Dovepress}

The manuscript management system is completely online and includes a very quick and fair peer-review system, which is all easy to use. Visit http://www.dovepress.com/testimonials.php to read real quotes from published authors. 